\title{
A DEMOCRATIC STATE GOVERNED BY THE RULE OF LAW - THE CONSTITUTIONAL IDENTITY OF THE CZECH REPUBLIC
}

\author{
Ondřej Preuss, \\ Charles University, Prague, \\ Faculty of Law, Senior Lecturer, Ph.D. \\ https://orcid.org/0000-0003-0779-8513, \\ The paper was prepared under the 'Progres 04' \\ programme of Charles University \\ preuss@prf.cuni.cz
}

\begin{abstract}
This article aspires to shed more light on the understanding of the notions of the constitutional identity, the material core of a constitution and unamendable elements of a constitution (eternity clauses) and on the concept of essential elements of a democratic state governed by the rule of law as reflected in the practice of the Czech Constitutional Court.

The Czech debate is not centred on the use of constitutional identity as a shield protecting local specifics. Quite the opposite. With a certain degree of generalization, we can conclude that the Czech notion of constitutional identity is, at least in the view of the Czech Constitutional Court, deeply grounded in such general concepts as democracy and the rule of law and connected with the material core of a constitution and unamendable elements of a constitution. However, this "legal“ concept of constitutional identity may easily conflict with a "popular" constitutional identity based primarily on traditional narratives about the formative events of Czech history as perceived by the Czech people and their elected representatives.
\end{abstract}

Keywords: the constitutional identity of the Czech Republic, the material core of a constitution, unamendable elements of a constitution, the eternity clause

\section{INTRODUCTION}

The Czech constitutional debate has long revolved around abstract terms such as the "material core" or „focal point" of the Constitution. Much discussion has taken place around which clauses in the Czech Constitution (if any) are unamendable or „eternal“ and constitute the essential elements of a democratic state governed by the rule of law. Such discussions can hardly avoid the concept of constitutional identity. As noted by Fabrini and Sajó, few concepts appear to be currently more à la mode among legal scholars than the notion of constitutional identity - a doctrine developed by apex state courts to generically shield areas of national legal systems from the influence of European law. Since 1992, Article 4 TEU has affirmed that the European Union shall respect member states' "national identities, inherent in their fundamental structures, political and constitutional, inclusive of regional and local self-government"(Fabbrini and Sajó, 2019, 457). 
Perhaps surprisingly, the Czech debate is not centred on the use of constitutional identity as a shield protecting local specifics. Quite the opposite. With a certain degree of generalization, we can conclude that the Czech notion of constitutional identity is, at least in the view of the Czech Constitutional Court, deeply grounded in such general concepts as democracy and the rule of law.

How have we arrived at this conclusion? The notion of constitutional identity is already well known to legal theory in a much broader sense (Ponthoreau, 2018), (Besselink, 2010), (Bogdandy and Sschill, 2011), (Mangoldt, 2002), (Sajó, 2019), (Faraguna, 2017). It has been analysed by Czech legal scholars, even though it has never stood in the centre of abovementioned debates (Grinc and Ondřejková, 2016). This article does not intend to address the question of whether or not the inclusion of the refined concept of respect for national identity in EU primary law via the Lisbon Treaty and its legal relevance significantly change the relationship between EU law and its national counterparts, although it is certainly possible to agree with Robert Zbíral that this relationship remains complicated and in many aspects, tense (Zbíral, 2014).

The purpose of this article is to demonstrate that, from the legal point of view, the Czech Constitutional Court identifies Czech constitutional identity with the ideals of the democratic rule of law, even though such a notion is conceptually inconsistent, and in fact somewhat self-contradictory. This is however the case, and despite its shortcomings, the approach also has undeniable positives in the current unstable post-pandemic world.

Czech constitutional identity in this legal sense of the term therefore really emerges from the belief that it is necessary to combine common historical experiences related to the past communist era and the necessity of building a democratic system after the collapse of the communist regime at the turn of the 1980s and 1990s.

It cannot however be concluded that the Czech constitutional identity is created merely by a specific mixture of solutions that are a legacy of the past, and solutions based on Western European patterns used as part of the political transformation, as President Havel's transnational ethos prevails over these influences.

However, as correctly pointed out by Kosař and Vyhnánek, this „legal“ concept of constitutional identity may easily conflict with a "popular" constitutional identity based primarily on traditional narratives about the formative events of Czech history as perceived by the Czech people and their elected representatives (Kosař and Vyhnánek, 2018). It is for a reason that we this year celebrate 100 year anniversary of the publication of Hašek's Švejk (Hašek, 1974), and that we last year did not celebrate 400 years from the defeat of the Bohemian Estates' army in the battle of Bílá Hora. The „Hungarian way“ therefore cannot be entirely ruled out and it may yet to prove that the constitutional identity might develop in a different direction than the one preferred by the Constitutional Court (Kosař and Vyhnánek, 2018, 868).

In order to understand what constitutes Czech constitutional identity in the legal sense of the term and in the rulings of the Constitutional Court, we must analyse other concepts; namely, the essential elements of a democratic state governed by the rule of law and the material core of the Constitution. 


\section{Material core of the Constitution and constitutional identity}

Lest a constitution be an empty shell, it must be filled with certain substance, which may be further divided into essential substance (which is crucial for the character of the constitution) and implementing substance (which elaborates on the basic principles). Just as a sales contract must include certain essential elements (essentialia negotii), such essential elements must also be present in the social contract, i.e., the constitution.

Formally, such essentialia negotii of the Czech Constitution are referred to as „essential elements of a democratic state governed by the rule of law“. They are however embedded in the Czech constitutional system only in Article 9(2) of the Constitution, which states that: Changes to the essential elements of a democratic state governed by the rule of law are not permissible. As Jan Filip reminds us, this express stipulation going beyond the original government-sponsored version of the Constitution was pushed through by President Havel. Jan Filip mentioned at the conference „20 years of the Czech Constitution“ that Václav Havel initially proposed to designate Articles 1 to 11 of the Constitution as essential elements of a democratic state governed by the rule of law. This was in the end rejected, partly due to fears of future interpretation problems foreshadowed by the German legal debate on a similar construction of the material core of German Basic Law embedded in Article 20 of the German Basic Law. It is however clear that any constitution contains certain essential elements or a material core without which it would no longer be the same constitution, even if no such provision is expressly stipulated in that constitution. Including such an express provision should however make the identification and delimitation of such unamendable elements easier.

However, since the concept is so broad and general and the Constitution does not offer any other normative guidelines for its interpretation, it is only natural that the interpretation of its true meaning evolves gradually through the body protecting constitutionality, the Czech Constitutional Court.

It is undisputed in legal theory that the above eternity clause on the essential elements of a democratic state governed by the rule of law is „inspired as to its ideological basis, wording and systemic placement in the constitutional system by Article 79(3) of the German Basic Law (1949), the „eternity clause“. (Ewigkeitsgarantie).“( Sládeček and Mikule and Syllová, 2007, 71).

The Constitutional Court uses the term „essential elements” interchangeably with the terms "material core" or "focal point" of the Constitution. It is beyond the scope of this article to closely analyse the differences between these two terms and they are therefore used herein as synonyms. According to the electronic databases of the decisions of the Constitutional Court (available at <http://nalus.usoud.cz/ $>$ ) the term „essential elements of the democratic state governed by the rule of law" appears in 175 judgments or resolutions of the Constitutional Court. The term „material core of the Constitution“ appears in scores of judgments and resolutions of the Constitutional Court. 21 judgments directly address the principle of the material rule of law. 10 judgments and 2 resolutions directly address the principle of eternity, while the principles of sovereignty of the people and the republican form of government were addressed by the Constitutional Court only in its „Lisbon judgments“. 
Decisions of the Constitutional Court however mostly refer to the material concept of the rule of law in a broader sense of the term, which is perceived by the Constitutional Court as a reflection of the notion of constitutional identity. According to the Constitutional Court, Czech constitutional identity does not refer to the glorious moments of Czech history, but rather to general guarantees of the democratic rule of law, or a constitutional democracy as such.

Acertain discrepancy can be identified here. According to the Constitutional Court, essential elements of a democratic state governed by the rule of law are identical to the material core of the Czech Constitution. Constitutional identity therefore equates to essential elements of the democratic rule of law.

Constitutional law theory however frequently understands the material core, hard core, or focal point of a constitution as a set of values which are characteristic for the given constitution (or constitutional system) (Holländer, 2005), which would be more consistent with the notion of constitutional identity than a general definition of essential elements of a democratic state governed by the rule of law further described below.

Pavel Molek writes that "the material core or focal point of the Constitution encompasses such rules which determine the very grounds of the constitutional system, i.e., they define the given constitution in such a sense that any change to them would result in an entirely different constitution and the existing constitution defined by them would no longer exist. Fusion of these two concepts into one, i.e., construction of the unamendable elements of a constitution in such a way that they are identical to its material core, is usually an unachievable ideal. (Molek, 2014, 138).

Every constitution should demark its territory, its people and how these people legitimize state power. This, according to Pavel Molek, constitutes the said „material focal point" of a constitution (Molek, 2014, 196).

It is therefore not possible to equate the material core of a constitution with essential elements of the democratic rule of law or unamendable constitutional provisions. A state may be a republic, monarchy, federation, or unitary state; it may be governed by a presidential or parliamentary system and such characteristics will be the defining elements of its constitutional system. They will however have no impact on whether the state is governed by the democratic rule of law, as these categories are entirely different.

Simply put, whether a state is a federation or a unitary state determines its very character (identity) but says nothing about its democratic fundaments. If we turn a monarchy into a republic, we will inevitably change the material core (focal point) of the state's constitution, while its democratic fundaments may remain completely unaffected.

The material core of the constitution therefore refers to constitutional identity, as understood by EU law, rather than the general principles of the rule of law, as illustrated by Judgement of the Court of Justice of the European Union (Second Chamber) of 22 December 2010. Ilonka Sayn-Wittgenstein v Landeshauptmann von Wien. C-208/09. In this case, Ms. Ilonka Sayn-Wittgenstein, an Austrian citizen residing in Germany was adopted by German citizen Lothar Fürst von Sayn-Wittgenstein and as a result acquired a name with the noble title of „Fürstin (countess) von Sayn-Wittgenstein“. This was initially registered in the Austrian register of civil status but following a decision by the Austrian constitutional 
court later replaced with a "civil“ surname of "Sayn-Wittgenstein“. With this ruling, the CJEU acknowledged that the EU does respect the national identity of its member states, which also includes the republican system of government. Gary Jacobsohn understands constitutional identity differently, as a sum of principles from which a given constitution should not deviate if it intends to retain stability in a society (Jacobsohn, 2010).

Constitutional identity may therefore be a slightly broader concept than the mere material core of the institution, which is a kind of extraction of only the most important features of a given constitutional identity. Should Austria permit the registration of a noble title into its register of civil status, that would represent an interference with its republican identity, but not necessarily with the material core of its constitution such as for example the restoration of the Austrian empire.

As stated above, the Constitutional Court of the Czech Republic makes a de facto equation not only between the material core of the constitution and constitutional identity, but also between these two concepts and the essential elements of a state governed by democratic rule of law, i.e., the Czech "eternity clause".

\section{Unamendable provisions and the „eternity clause“}

However, the unamendable or „eternal“ provisions in fact also belong to an entirely different category than the material core or focal point of a constitution. Their purpose is to rule out any changes to the principles, norms and values essential to the constitutional system of a given state. A typical example of such an eternity clause is Article 9(2) and (3) of the Czech Constitution.

The earliest known express eternity clause was embedded in the 1798 Constitution of the Swiss Helvetic Republic, which proclaims in the last sentence of Article 2: „Even if changed in the future, the form of government must forever remain representative democracy." Certain clauses in the constitution of post-colonial Delaware and New Jersey from 1776 could be considered even older predecessors of eternity clauses. However, since the Helvetic Republic emerged in the wake of a French invasion, it is not surprising that it ceased to exist after a mere four years along with its constitution. Besides representative democracy one of the main defining features of the Helvetic Constitution was strong central government both of which are in direct opposition to what has Switzerland been known for at least since the beginning of 19th century - strong federalism and an unusually wide use of direct democracy (in particular on the cantonal level). As Pavel Molek says, the example of the Helvetic constitution was not exactly encouraging for the fate of "eternity clauses“ in European constitutions (Molek, 2014, 35).

The oldest existing eternity clause is to be found in the 1814 Norwegian Constitution, which is the second oldest existing constitution in the world. The Norwegian eternity clause outlaws any changes to the basic spirit and principles of the Constitution (Article 112). As Eivind Smith writes, the Norwegian „eternity clause“ has ensured the smooth constitutional development of the Kingdom of Norway, but it has failed to ensure the survival of some of its original founding principles, which were deeply monarchist (Smith, 2011). That means that despite its declared objective having failed, another, just as noble, goal has been achieved. It is somewhat ironic, but herein perhaps lies the true power of "unamendable clauses". 
Many more examples of eternity clauses can be found around the world, some of them rather peculiar. The 1924 Mexican Constitution established that the only religion of the Mexican nation is and forever will be Apostolic Roman Catholicism. Quatar's 2004 constitution enacts the inviolable position of the emir. Several constitutions adopted in Niger enacted „eternal“ amnesties for perpetrators of certain crimes against humanity. The Constitution of the Fifth Republic of Niger from 8 July 1999 stated in Article 134 that no changes to the last article of the Constitution, i.e., Article 141, are permissible. Said Article stipulates: Amnesty is given to perpetrators of attempted coups d'état from 27 January 1996 and 9 April 1999. (Roznai, 2017).

Modern eternity clauses are however inspired mostly by a French constitutional amendment of 1884, which laid down the republican system of government as an eternal principle of the state, and in particular by German Basic Law, whose Article 79(3) prohibits any changes concerning the division of the federation into states, participation of the federal states in the legislative procedure or principles enumerated in Articles 1 and 20 of the Basic Law (republican form of government, principles of democratic, federative and welfare state, sovereignty of the people, separation of powers, constitutionality of the legislative process and legality of the executive and judicial powers). It is a frequently voiced opinion that the Basic Law was drafted with memory of the failure of the Weimar Republic (Lapčáková, 2009). Many famous decisions of the Indian Supreme Court and the entire Indian approach to this issue have been inspired by the German legal environment (Roznai, 2013).

What does then constitute the difference between the material core of a constitution and its unamendable provisions? Let Pavel Molek's metaphor help us understand: „...should we compare the constitution to a medieval castle, then the material core is the centre of the castle, the main tower, without which the rest of the castle will have no purpose and become a mere walled cluster of random buildings; on the other hand, the unamendable elements may be compared to fortification walls which we usually build at the place where the last attack came from. ...In contrast to the unamendable elements, the material core of a constitution does not need to aspire to eternity, quite the opposite. It may be fluid and its meaning may shift just as a people's perception of the defining features of a given constitution does." (Molek, 2014).

An eternity clause is therefore a practical instrument rather than the essence of a constitutional system. It plays a similar role to other tools protecting the rigidity of the constitution, such as a qualified majority, confirmatory referendums etc.

It is therefore up to us, or rather up to the constituent legislator, to decide which principles deserve stronger protection. It is mere coincidence, that in the Czech Republic such protection is designed very broadly and generally as it tries to "fortify“ all the essential elements of the democratic rule of law.

That brings us to the heart of the problem, which is a definition of what the Constitutional Court perceives as Czech constitutional identity - i.e., the concept of the essential elements of a democratic state governed by the rule of law.

\section{Essential elements of a democratic state governed by the rule of law}

The essential elements of a democratic state governed by the rule of law cannot be equated to unamendable constitutional provisions or the material core of the Czech Constitution, and, despite what the Constitutional Court asserts, not even to the constitutional identity of 
the Czech Republic. Constitutional Court Justice Kateřina Šimáčková uses the term explicitly in her dissenting opinion. She argues that the Czech constitutional identity also includes two specific constitutional provisions based on Czech historical experience which includes closed borders and shooting at refugees trying to cross the borders during the communist regime (Resolution of the Constitutional Court No. Pl. ÚS 13/20 from 5 May 2020).

The notion of essential elements of a democratic state governed by the rule of law is rather fluid and general defined by an ever-evolving set of characteristics.

The notion therefore differs from the other concepts explained above. In Czech discourse, it is however often incorrectly used interchangeably with both the material core of the Constitution and its unamendable elements.

Pavel Holländer defines the term very broadly when he sees the material essence of the system not in the Constitution or any parts thereof, but in values and principles which are in principal independent of the Constitution (Sládeček and Mikule and Syllová, 2007). A commentary written by the "fathers of the constitution“ Dušan Hendrych and Cyril Svoboda defines the essential elements of the rule of law more narrowly as the principles encompassed in Article 1(1), Article 5 and Article 6 of the Constitution (Hendrych and Svoboda, 1997). Václav Pavlíček and Jiří Hřebejk's commentary goes only slightly further and adds reference to the sovereignty of the people embodied in Article 2(1) of the Constitution (Pavlíček and Hřebejk, 1998). Other authors naturally attempt to define the essential elements of a Czech democratic state governed by the rule of law (Šimíček, 2009), (Wintr, 2006).

A number of constitutional lawyers have tried to define the democratic rule of law (or its essential elements) more precisely. These efforts have culminated in the monograph authored by Maxim Tomoszek, which deals not only with the essential elements of a democratic state governed by the rule of law, but also with the notion and the principles of the democratic rule of law as such (Tomoszek, 2016).

According to Tomoszek, the essential elements of the democratic rule of law are a subset of elements which define the concept of the democratic rule of law as such (Tomoszek, 2016). His understanding of the essential elements of the rule of law is value based rather than formal, which means that respect for the principles of democratic decision-making and for the formal aspects of the rule of law is not sufficient. It is also necessary to honour the material essence of the rule of law. Further, the ultimate definition of the democratic rule of law must encompass all of the following principles: legal certainty, separation of powers, protection of basic human rights and democracy (Tomoszek, 2016).

Attempts to closely define the essential elements of a democratic state governed by the rule of law are not limited to legal theory. The Constitutional Court has, quite understandably, repeatedly refused to provide an exhaustive catalogue or list of elements which it considers essential for the preservation of the democratic rule of law. Nonetheless, several of its past decisions offer certain clues. Decisions no. Pl. ÚS 19/93, III. ÚS 31/97, Pl. ÚS 36/01 and Pl.ÚS 19/08 revealed that the Constitutional Court understands the essential elements of the democratic rule of law materially rather than formally and that it gives utmost priority to specific legal principles, rights and democratic values. It appears that for the Constitutional Court, the guiding constitutional principle, i.e., the „essential element" is the priority of individual rights, such as the fundamental human and civil rights embodied in the natural 
law sections of the Charter of Fundamental Rights and Freedoms. Case law produced by the German Constitutional Court perceives human dignity as the highest value of the Basic Law (explicitly in a judgment of the Constitutional Court of the Federal Republic of Germany from 10 May 1957, no. BVerfGE 6 (1957)).

Already in Pl. ÚS 19/93 from 21 December 1993 which addressed Act No. 198/1993 Sb., on Illegality of the Communist Regime and on Resistance Against It, the Constitutional Court asserted that „... our new constitution is not based on value neutrality..., but encompasses regulative ideas which protect the basic untouchable values of democratic society..., it does not require only the formal legality of positive law, but ties the interpretation and application of legal rules to their material essence, i.e., requires that the law respects the basic constitutive values of democratic society and at all times measures the application of legal rules against these values. This means that even though there might be a formal continuity with the ,old law', there is a value discontinuity with the ,old regime."

In its decision no. I.ÚS 517/10 from 15 November 2010 on mandatory disclosure of membership of judges in the Czechoslovak Communist Party, the Constitutional Court repeated that major political and economic changes occurred in Czechoslovakia after the Velvet Revolution. As a result, a new system of values based on modern democracy has been introduced, through whose lens it was - and still is - necessary to interpret both existing and former legislation, where still applicable. The Constitutional Court has repeatedly ruled that the purpose and meaning of legislation cannot be sought only in the wording of an individual piece of legislation, but that the basic principles acknowledged by democratic states must always be respected.

This represents a sharp departure from the values and principles asserted by the previous regime. However, that is only a general proclamation and negation of the past. What are the specific positive material values honoured by the new regime?

In its decision no. I.ÚS 420/09 from 3 June 2009 on constitutional requirements for the publication of international treaties, the Constitutional Court ruled that since „..the main purpose of the state and state power is without doubt to ensure respect for the rights and freedoms of the individual, the concept of the democratic rule of law must be construed accordingly." This decision refers to an older decision of the Constitutional Court no. Pl. ÚS 43/93 from 12 April 1994 on the criminal offence of defamation of Parliament, Government and the Constitutional Court (interpretation of the legal terms of presidential decision and countersignature) and quotes the following section: "Principles of the democratic rule of law are based on the priority of the citizen before the state, and thereby on the priority of basic human and civil rights and freedoms".

It seems that, according to the Constitutional Court, the leading principle of Czech constitutionalism is the priority of the individual rights of natural persons and the protection of fundamental human rights embodied in the natural law provisions of the Charter of Fundamental Rights and Freedoms. However, this does not exhaust the concept of essential elements of the Constitution.

Other specific principles and constitutional provisions which reflect the essential elements of the democratic rule of law can be systematically divided into political rights, or democratic principles, and two rather broad cross-cutting areas, which are naturally the main focus of 
the Constitutional Court, i.e., the legislative process and application of law in general.

The legislative process overlaps with all the other categories. According to the Constitutional Court, the fundamental principles of the rule of law include the principle of predictability of the law, its clarity and non-contradictory nature. For example, in judgment no. Pl. ÚS 77/06 of the Constitutional Court from 15 February 2007 on legislative riders and their constitutionality.

The famous „Melčák“ decision (no. Pl.ÚS 27/09 from 10 September 2009), in which the Constitutional Court stood up to the constituent legislator itself, when it appealed to the Czech eternity clause and abolished a special constitutional law which prematurely ended the term of the then-current Chamber of Deputies, made a rather clear, albeit controversial, conclusion, that the essential elements of the democratic rule of law also include the law's general character and a ban on genuine retroactivity. This decision provoked strong reactions not only among legal theorists. A deeper reflection is beyond the scope of this article as it infers a pool of other constitutional questions.

Should we need a summary of the essential elements of the democratic rule of law, the best place to look would be the Constitutional Court's first "Lisbon judgement" (no. Pl.ÚS 19/08 from 26 November 2008), which says that „...Already in the preambles to the Charter of Fundamental Rights and Freedoms and the Constitution did the constituent legislator express an unconditional commitment to the values which stand as the fundaments of our constitutionalism; it, among other things, acknowledged the inviolability of the natural rights of individuals based on the universally shared values of humanity and expressed a determination to protect and develop the Czech Republic in the spirit of the inviolable values of human dignity and freedom, and the will to stand alongside states which honour these values as a member of the family of European and global democracies. With respect to the wording used in the Constitution and the Charter of Fundamental Rights and Freedoms, Article 1(1) of the Constitution and Article 1 of the Charter of Fundamental Rights and Freedoms are essential as they proclaim that the Czech Republic is a sovereign democratic state governed by the rule of law based on respect to inviolable and indefeasible rights and freedoms of people, free and equal in their rights and dignity. The rights and freedoms of minorities in general and from a national and ethnic perspective are provided for in Article 6 of the Constitution (which renders their protection mandatory) and in the third Chapter of the Charter of Fundamental Rights and Freedoms. The ban on discrimination is provided for in particular in the section on the economic and social rights of the Charter of Fundamental Rights and Freedoms; the political system itself is, according to Article 5 of the Constitution, based on free competition of political parties which reject violence as means of advancing their interests and which respect fundamental democratic principles."

In the famous case of "Slovak pensions" (sometimes also referred to as „Holubec"), the Constitutional Court upheld a complaint made by former train driver Karel Holubec despite the opposite opinion of the CJEU, which the Constitutional Court proclaimed to be „ultra vires". The Constitutional Court thus placed the material core of the Czech Constitution and the protection of individual rights beyond the international obligations of the Czech Republic (Judgment of the Constitutional Court No. Pl. ÚS 5/12). The irony of the case is that the claimant achieved no real satisfaction since his pension after the end of the dispute had 
already reached the demanded amount and he was therefore not entitled to any additional compensation. The dispute was therefore purely formal.

It is therefore clear that by including social rights, the Czech Constitutional Court understands the essential elements of a democratic state governed by the rule of law rather broadly. At the same time, it is possible to trace a clear pattern in the understanding of the term in the practice of the first two Constitutional Courts, which can be manifested in two postulates. The first is the priority given to the protection of individuals and their "natural“ rights. The second is the rule of law, which even the parliamentary majority must obey.

Nevertheless, such inspiration drawn from the "activist" German Constitutional Court is "drying up", which candidates for the European Parliament for the Pirate Party and the Green Party learnt the hard way when the Constitutional Court failed to defend them, contrary to its German counterpart, and did not abolish the electoral threshold (Judgment of the Constitutional Court No. Pl. 14/14).

It appears that particularly "Milos Zeman's Constitutional Court," now fully appointed by the re-elected President, will not be willing to continue in the direction set by the "Melčák" case. However, the Constitutional Court is still prepared to defend the values of liberal democracy, albeit not in such a spectacular manner.

Most importantly, the Constitutional Court continues to create the impression that the essential elements of the democratic rule of law are identical to the material core of the Constitution, its unamendable provisions and thereby the constitutional identity itself.

It is therefore necessary to reiterate that it is not a generally shared opinion that the essential elements of the democratic rule of law are identical to the eternity clauses enacted in constitutional legislation. Some constitutions identify as „unamendable“ a form of government (such as the republican system of government in France or Turkey), the state's territory (Ukraine) or certain specific values protected by the constitution (Germany or Romania).

Moreover, the Czech constitution works with one more as yet unclassified category, namely the "fundaments of a democratic state" referred to in Article 9(3) of the Constitution. Differences between "essential elements of a democratic state governed by the rule of law" and "fundaments of a democratic state", if any, are yet to have a significant impact on legal theory and practice. As Pavel Molek says, the idea of „rational legislator“ implies that identical concepts should not be referred to by different terms. Molek therefore does see a difference between these two concepts. In his opinion, Article 9(2) defines the unamendable elements of the Constitution, while the objective of Article 9(3) is to protect its material core (Molek, 2014).

Maxim Tomoszek asks whether the distinction is caused by mere omission or a lack of attention paid to the drafting process of the Constitution and concludes that the distinction is likely intentional and symbolizes a relationship between the principles of democracy and the rule of law (Tomoszek, 2016).

An intentional use of two different terms might also be a nod to the future interpreters of the Constitution (in particular to the Constitutional Court) reminding them to pay heed to the democratic character of the state. Whether this has any practical impact is not entirely clear and there is actually more ambiguity than clarity about the matter. 


\section{CONCLUSION}

This article aspires to shed more light on the understanding of the notions of the constitutional identity, the material core of a constitution and unamendable elements of a constitution (eternity clauses) and on the concept of essential elements of a democratic state governed by the rule of law as reflected in the practice of the Czech Constitutional Court.

The material core or the focal point of the constitution is one of the defining features of the constitutional system. Just as sparkling wine without bubbles would still be „wine“ but no longer "sparkling“, a concrete constitution without its core would remain a constitution, but of an entirely different kind.

This however does not mean that these „bubbles“ are necessarily identical to the essential elements of a democratic state governed by the rule of law. There are many kinds of wine and therefore, a democratic state governed by the rule of law may also have quite different character, such as a republic or a monarchy.

Application of the above concepts has very specific effects on the law-making process, decisions of the Constitutional Court, and legal practice in general. It is therefore necessary to define and make a clear distinction between them, even though they may overlap in specific cases.

Although it is desirable to "draw a clear line“ between the concepts of the essential elements of the democratic rule of law and the material core of the Constitution, we may conclude that from a legal point of view, the Constitutional Court subjects all these terms to the same standard, namely the priority of the individual and the protection of the fundamental rights of man and citizen as embodied in the natural law provisions of the Charter of Fundamental Rights and Freedoms. It is through this prism that the constitutional identity of the Czech Republic should be seen.

The Czech Constitutional Court actually goes as far as to equate the Czech constitutional identity with the above concepts, i.e., with material principles of the rule of law, despite the conceptual inconsistency and contradiction embedded in such an approach.

As mentioned in the introduction, despite its limitations, there are certain positive effects to such a view. An express commitment to the protection of the rights of the individual may not correspond to the „popular“ perception of the Czech constitutional identity, it may however serve as a useful argument in specific legal cases.

\section{REFERENCES}

Besselink, L. F. M. (2010). National and Constitutional Identity before and after Lisbon. Utrecht Law Review, vol. 6, no. 3 .

Bogdandy, A. von - Sschill, S. (2011). Overcoming Absolute Supremacy: Respect for National Identity under the Lisbon Treaty. Common Market Law Review, vol. 40, no. 5.

Fabbrini, F. Sajó, A. (2019). The Dangers of Constitutional Identity. European Law Journal, vol. 25, no. 4, 457-473. DOI 10.1111/eulj.12332

Faraguna, P. (2017). Constitutional Identity in the EU. A Shield or a Sword? Germal Law Journal. vol. 18, no. 7, DOI:10.1017/S207183220002246X 
Grinc, J., Ondřejková, J. (2016). Stát a nadnárodní integrace. Případ Evropské unie. [State and International Integration. Example of the European Union.] In: Kysela, J. - Ondřejek, P. Kolos na hliněných nohou? K proměnám státu a jeho rolí. [State as a Giant with Feet of Clay]. Praha. Leges.

Hašek, J. (1974). The Good Soldier Švejk and his Fortunes in the World War. London. Penguin Books.

Hendrych, D. and Svoboda, C. (1997). Ústava České republiky: komentář. [Constitution of the Czech Republic: Commentary]. $1^{\text {st }}$ ed. Praha. C. H. Beck.

Holländer, P. (2005). Materiální ohnisko ústavy a diskrece ústavodárce. [Material Core of the Constitution and Discretion of the Constituent Legislator]. Právník, vol. 144, no. 4.

Jacobsohn, G. J. (2010). Constitutional Identity. Cambridge, Massachusetts. Harvard University Press.

Kosař, D. Vyhnánek. L. (2018) Ústavní identita České republiky [Constitutional Identity of the Czech Republic], Právník, vol. 157, no. 10, 855.

Lapčáková, M. (2009). Materiálne jadro základného zákona Spolkovej republiky Nemecko z pohladu Spolkového ústavného súdu. [Maerial Core of the Basic Law of the Federal Republic of Germany in the View of the Federal Constitutional Court]. IN Ondrej Hamulák (ed.). Fenomén judikatury v právu. [The Phenomenon of Case Law]. Olomouc. Leges

Mangoldt, H. von. (2002). L'identité des Etats membres de l'Union européenne. In: Vitzthum, W. Peňa, M. (eds). L'identité de l'Europe. W. Marseille. PUAM.

Molek, P. (2014). Materiální ohnisko ústavy: věčný limit evropské integrace? [Material Core of the Constitution: An Eternal Obstacle to EU Integration?]. 1st ed. Brno. Masaryk University.

Pavlíček, V. and Hřebejk, J. (1998). Ústava a ústavní řád České republiky: komentář. [Constitution and Constitutional System of the Czech Republic: Commentary]. $2^{\text {nd }}$ exp. ed. Praha. Linde.

Ponthoreau, M.C. (2018). Interpretations of the National Identity Clause. In: Baroncelli, Stefano et al. Back to Maastricht: Obstacles to Constitutional reform within the EU Treaty (1991-2007). Newcastle. Cambridge Scholars Publishing.

Roznai, Y. (2013). Unconstitutional Constitutional Amendments - The Migration and Success of a Constitutional Idea. American Journal of Comparative Law, vol. 61.

Roznai, Y. (2017). Unconstitutional Constitutional Amendments - The Limits of Amendment Powers, $1^{\text {st }}$ ed., Oxford.

Sajó, A. (2019). On Constitutional Identity and the Loyalties of the Constitutional Judge. Cardozo Law Review, vol. 40, no. 6, 3253-3276.

Sládeček , V., Mikule, V. and Syllová, J. (2007). Ústava České republiky: komentář. [Constitution of the Czech Republic: Commentary]. $1^{\text {st }}$ ed. Praha. C.H. Beck

Smith, E. (2011). Old and Protected? On the „Supra-constitutional“ Clause in the Constitution of Norway. Israel Law Review. vol. 44, $3^{\text {rd }}$ ed.

Šimíček, V. (2009). Materiální ohnisko ústavního pořádku, jeho ochrana a nález Ústavního soudu ve věci M. Melčáka. [Material Core of the Constitutional System and its Protection and the Melcak Judgment of the Constitutional Court]. In Vladimír Klokočka - liber amicorum. $1^{\text {st }}$ ed. Praha. Linde,

Tomoszek, M. (2016). Podstatné náležitosti demokratického právního státu. [Essential Elements of a Democratic State Governed by the Rule of Law]. $1^{\text {st }}$ ed., Praha. Leges,

Wintr, J. (2006). Principy českého ústavního práva s dodatkem principů práva evropského a mezinárodního. [Principles of Czech Constitutional Law with Reflections on Principles of European and International Law]. $1^{\text {st }}$ ed. Praha. Eurolex Bohemia,

Zbíral, R. (2014). Koncept národní identity jako nový prvek ve vztahu vnitrostátního a unijního práva: poznatky z teorie a praxe. [The Concept of National Identity as a New Element in the Relationship between National and EU Law: Lessons from Theory and Practice]. Právník, vol. 153, no. 2, 133. 